\title{
lodine I 124 Monoclonal Antibody M5A
}

National Cancer Institute

\section{Source}

National Cancer Institute. Iodine I 124 Monoclonal Antibody M5A. NCI Thesaurus. Code C158629.

A radioimmunoconjug ate comprised of $\mathrm{M} 5 \mathrm{~A}$, a humanized monoclonal antibody directed against carcinoembryonic antigen-related cell adhesion molecule 5 (CEA or CEACAM5), labeled with iodine I 124 (I-124) with potential radiolocalization applications. Upon administration, the antibody moiety of iodine I 124 monoclonal antibody M5A specifically binds to cells expressing CEA. Upon binding, the radioisotope moiety can be detected using positron-emission tomography (PET), thereby allowing the imaging and quantification of CEA-expressing tumor cells. CEA, a tumor associated antigen and a member of the CEA family of proteins, plays a key role in cell migration, cell invasion, and cell adhesion and is overexpressed by a variety of cancer types. 